v. $12, n .4$

Vitória-ES, Jul.-Aug. 2015

p. $57-78$ ISSN 1808-2386

DOI: http://dx.doi.org/10.15728/bbr.2015.12.4.3

\title{
The Brand's Effect on the Evaluation of Advertising Endorsed by Celebrities: an Experimental Study
}

\author{
Leonardo Aureliano-Silva ${ }^{\dagger}$ \\ Nove de Julho University \\ Evandro Luiz Lopes ${ }^{\Omega}$ \\ Nove de Julho University / Federal University of São Paulo \\ Otávio Bandeira De Lamônica Freire ${ }^{¥}$ \\ Nove de Julho University / University of São Paulo \\ Dirceu da Silva ${ }^{ \pm}$ \\ Nove de Julho University
}

\begin{abstract}
Celebrity endorsement aims to influence consumers to buy advertised products. In endorsing products, celebrities transfer their attributes to the objects, making them more desired by consumers. Celebrity endorsement is a promotional technique to better integrate brand, product and message, thus justifying the high investments by companies to engage celebrities. Although well established, the phenomenon lacks scientific studies that explain, based on the concept of celebrity congruence, the alignment between the celebrity's profile and the product, also considering brand strength. After an extensive literature review, we performed three experiments, involving 713 respondents, to verify the effect of celebrity endorsement with different levels of congruence with the product, while manipulating the brands. The results of analysis of variance indicated a significant positive effect of celebrity endorsement with high congruence for unrecognized brands, but not for recognized brands.
\end{abstract}

Keywords: Endorsement. Celebrity. Brand. Congruency. Advertising.

Received in 10/14/2013; revised in 12/05/2013; acceptd in 01/20/2014; disclosed in 07/01/2015

*Author for correspondence:

$\dagger$. Doctoral student in

Administration at Nove de Julho University

Institution: Professor at Nove de Julho University

Address: Rua São Ladislau, São

Paulo - SP - Brazil

E-mail:

leonardoaureliano@outlook.com

Telephone: (11) 9-5876-3958

$\Omega$ PhD in
Administration from
Nove de Julho University
Institution: Professor at
Nove de Julho University
and Federal University of
São Paulo
Address:: Rua Serra de
Bragança, São Paulo -
SP - Brazil
E-mail:
elldijo@ uol.com.br
Telephone: (11)
981468992

${ }^{¥} \mathrm{PhD}$ in Communication from Federal University of São Paulo

Institution: Professor at Nove

de Julho University and

University of São Paulo

Address: Rua Otávio de

Morais, Cidade São Francisco,

São Paulo - SP - Brazil

E-mail:

otaviofreire@uninove.br /

otfreire@usp.br

Telephone: (11) 9 8339-5500 $\ddagger$ PhD from the School of Education of Federal University of São Paulo Institution: Professor at Nove de Julho University Address: Via das Magnólias, Cotia, São Paulo - SP

Brazil

E-mail: dirceuds@gmail.com

Telephone: ( 11 ) 47028279

Note from the Editor: The article was accepted by Emerson Mainardes. 


\section{INTRODUCTION}

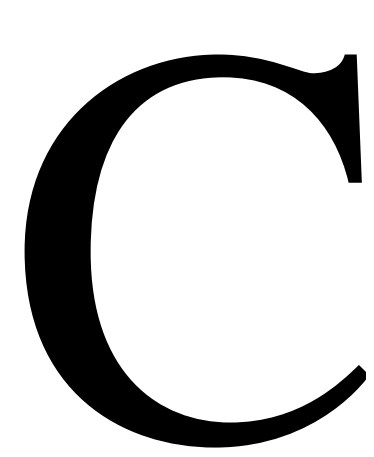

elebrity endorsement is a well-established marketing strategy used in many countries (CHOI, LEE; KIM, 2005, KIM; NA, 2007, GUREL; KAHLE, 2010). In India, for example, more than $60 \%$ of advertisements use this strategy (SUBHADIP, 2010), while the global figure is between 25\% and 30\% (AGRAWAL; KAMAKURA, 1995; SHIMP, 2000, CHOI et al., 2005).

Studies in many fields have sought to understand the influence of celebrity on society, individuals and fans (McNAMARA, 2009). In the field of marketing, however, the influence of celebrity endorsement on consumer behavior still deserves further attention.

Individuals who revere celebrities tend to have a more positive assessment of the products and brands endorsed by their idols. For the average person, celebrities represent a dream they would like to attain (ROCKWELL; GILES, 2009). The purpose of celebrity endorsement is to influence the response of individuals regarding the evaluation and consumption of products or services. Fans establish psychological ties with the celebrity that leads them, at least theoretically, to purchase products or services identified by brands that project attributes of their idols.

The use of celebrities in advertising is justified by the influence they have on fans and the public in general, stimulating the purchase of the endorsed products or services (TRIPP; JENSEN; CARLSON, 1994). For the fan, the celebrity is qualified to evaluate and recommend products and brands, and the desire to emulate, be equal to or even become a celebrity only requires purchasing the products identified by the endorsed brand (KIM; NA, 2007; McNAMARA, 2009).

Therefore, analyzing this phenomenon can make substantial contributions to marketing strategies, besides providing support for communication practices of public and private organizations. Our literature review revealed a relative lack of studies integrating brand and celebrity, opening space to pose the following question: What is the effect of the brand on the evaluation of advertisements containing celebrity endorsements?

This paper is organized in four sections including this introduction. In the next section we present the theoretical framework while in the third we formulate the hypotheses, design and general plan for analysis of the experiments. In the fourth section we discuss the aggregate results, indicate their limitations and propose some avenues for future research. 


\subsection{CELEBRITIES IN ADVERTISING}

Celebrities are well-known people who are recognized or show exceptional performance in a determined area, be it professional competence or physical beauty (KAHLE; HOMER, 1985; BAKER; GILBERT, 2007), such as actors and athletes (FRIEDMAN; FRIEDMAN, 1979). They can use this public recognition in favor of products or brands (McCRACKEN, 1989). Celebrity endorsement is a promotional technique to enhance the integration of brand, product and message, justifying the high investments by companies (CHARBONNEAU; GARLAND, 2005; CHOI et al., 2005; CHOI; RIFON, 2007; KIM; NA, 2007, BANYTÈ; STONKIENÈ; PILIGRIMIENÈ, 2011). The influence of celebrities on their fans occurs by imitation or admiration of a specific public group. Assiduous fans quickly adopt the products endorsed or merely used by singers, athletes and actors, while others may only dress the same or use the same hairstyle. The relationship is strengthened by the wide disclosure of the backstage details and news of the personal life of the celebrity in the media (MEYERS, 2009). Petty and D'Rozzario (2009) indicate that celebrities, because of their success, attract the curiosity of fans and the public in general, which justifies the use of their images in marketing and communication actions.

When celebrities and brands are presented together, consumers form associations between the two, enabling the transfer of meanings of celebrity to the brand, positively or negatively affecting the latter's image (TILL; SHIMP, 1998). The greater the credibility the celebrity transfers to the endorsed brand, the more positively it will be evaluated (SLIBURYTE, 2009). For McCracken (1989), the world of celebrities is one of the most potent sources of cultural meaning related to the marketing system.

Despite the generally positive aspects of endorsement, in some cases celebrities cannot substantially help promote products (MISRA; BEATTY, 1990). Academic treatises demonstrate that experience, credibility, physical beauty and charisma are the main variables to be considered in contracting a celebrity (TILL; SHIMP, 1998, SLIBURYTE, 2009).

It is relevant to consider the adequacy of the celebrity to recommend a determined product or brand. The word used for the alignment between celebrity and product/brand is congruence. According to Kim and $\mathrm{Na}$ (2007), congruence is a set of attributes that makes the public perceive the celebrity as fit to endorse a determined product or brand. The transfer of the celebrity's attributes to the product, especially in situations of high congruence, is also explained by McCRACKEN (1989), who identified the effect of this phenomenon to strengthen the desire to buy. 
The use of celebrities in advertising is justified, then, by the influence they exert on fans and the public in general, stimulating the purchase of products or services identified by the brands they endorse. For fans, the celebrity is fully qualified to evaluate and recommend products and brands, and the desire to be equal to or even become a celebrity only requires purchasing the products or services designated by the brand endorsed by the idol (KIM; NA, 2007, McNAMARA, 2009).

The theory of celebrity endorsement affirms that a celebrity exercises influence over individuals, positively or negatively affecting their behavior, by serving as role models. In marketing, celebrities are used in the hope they will positively influence consumers' behavior in favor of a product or service (TRIPP; JESEN; CARLSON, 1994). Characteristics of the celebrity, such as physical good looks and charisma, appear to be sufficient. Many studies have been carried out investigating the profile of famous people to recommend a determined product. As mentioned, the fit between the celebrity and brand is called congruence (GUREL; KAHLE, 2010). Therefore, congruence is the adjustment of a celebrity's profile to profess the advantageous characteristics or benefits of a product in an advertisement. According to Kim and $\mathrm{Na}$ (2007), when the celebrity has high congruence with the product, consumers tend to assess it more positively.

\subsection{BRANDS}

The objective of a trademark or brand is to identify the manufacturer of a product, differentiating it from others offered and aggregating value to the product, helping to obtain a competitive advantage (CAPUTO; MACEDO; NOGUEIRA, 2008; GONÇALVES FILHO; SOUKI; GONÇALVES, 2009). Competitive advantage is achieved by brands that communicate benefits to customers, establishing ties of trust (ALEX, 2011). For Rao and Monroe (1989), brands reduce the risks perceived by consumers because they indicate quality, reliability or other positive attributes, making buying decisions easier and stimulating positive word-of-mouth (BATRA; AHUVIA; BAGOZZI, 2012). In this sense, brands serve as diagnostic stimuli, enabling consumers to evaluate the product more quickly and securely.

In the opinion of Keller, Heckler and Houston (1998), the brand name is decisive for the success of a product, by conveying attributes desired by consumers. Because of the benefits that a brand communicates to consumers, many companies use brand extension strategies (SCHMIDT; GUIMARÃES, 1985).

Some customers are willing to pay more for a product to acquire their favorite brand (KELLER, 2003; ALAWADI; LEHMAN; NELSIN, 2003). A strong brand has a high level of 
recall and loyalty among consumers (RUST; LEMON; ZEITHAML, 2004), to the point that some brands become synonyms for the category of the product they designate (CAPUTO et al., 2008).

In the minds of consumers, quality is not necessarily related to the product's technical specifications, nor is it ascertained by careful analysis of its characteristics. The quality considered by consumers in general is related to a broad and intangible feeling regarding the brand attached to the product (KELLER, 2003), making it an element with strong influence on the buying decision process, in any circumstance.

\subsection{BRANDS AND CELEBRITY ENDORSEMENT}

The relationship between endorsement and brand can be understood by the intangible elements the celebrity transfers to the brand, such as personal attractiveness, which affects the level of involvement with the product (KAHLE; HOMER, 1985). For the process of transfer of attributes by means of endorsement to occur satisfactorily, the literature suggests there needs to be congruence between the celebrity and the product or brand endorsed. Congruence is the coherence between the announced product and the profile of the endorser (KIM; NA, 2007).

Both the celebrity and the brand need to convey to consumers the feeling that by purchasing a certain product, they will attain their objectives. Brands and celebrities represent the desires, hopes and dreams of the common consumer (ROCKWELL; GILES, 2009). Because they represent these hopes and dreams, brands need to be managed to assure the promised standard of quality.

The choice of a celebrity to endorse a brand will not have a positive effect on all consumers. People who are not attracted to the celebrity can reject the product, as observed by Wong et al. (2010).

Good sense in choosing a celebrity to endorse specific brands or products goes beyond fan approval. When endorsing a brand, the celebrity needs to assume a commitment to the company and the public in general, and more specifically to fans, that what is promised will be delivered.

The success or failure (e.g., poor performance or scandal) of a celebrity can affect the brand, while the contrary can also occur. If the endorsed product or brand does not find good acceptance in the market, the celebrity's image can be tarnished by the negative aspects consumers perceive in purchasing a product with poor quality. 
Despite the large number of international studies on celebrity endorsement, we did not find any that have investigated the use of this strategy weighted by congruence and moderated by the strength of the brand. Based on the literature review, in the next section we present the hypotheses to be tested.

\section{FORMULATION OF THE HYPOTHESES}

Studies in other fields of knowledge have reported the influence of celebrities on individuals, in particular on their fans (MEYERS, 2009; McNAMARA, 2009; SLIBURYTE, 2009). This influence forms the first hypothesis to be tested:

$\mathrm{H} 1$ - The presence of a celebrity in advertising will have a positive influence on the evaluation of the product.

\section{Experiment 1}

The objective of Experiment 1, then, was to analyze the effect of celebrity endorsement on the evaluation of a product.

\subsection{DEFINITION OF THE STIMULI OF EXPERIMENT 1}

In this experiment, the stimuli were an advertisement for a fan, an object of common use with accessible price, and the endorsement was provided by the image of Ivete Sangalo, a popular singer instantly recognizable by most Brazilian consumers due to her broad media exposure.

\subsection{GENERAL DESIGN OF THE DATA COLLECTION INSTRUMENT}

To analyze the effect of the brand in advertisements with the presence of a celebrity endorser, we used electronic questionnaires (posted on the Questionpro website) adapted for each of the three experiments. In all cases, the first section of the questionnaire presented an advertisement for a product to be launched in the near future.

In Experiment 1, in the first block of the data collection instrument we presented an advertisement for the product without any endorsement to one group of respondents and the same ad with endorsement to another group. Figures 1 and 2 show the stimuli utilized. 


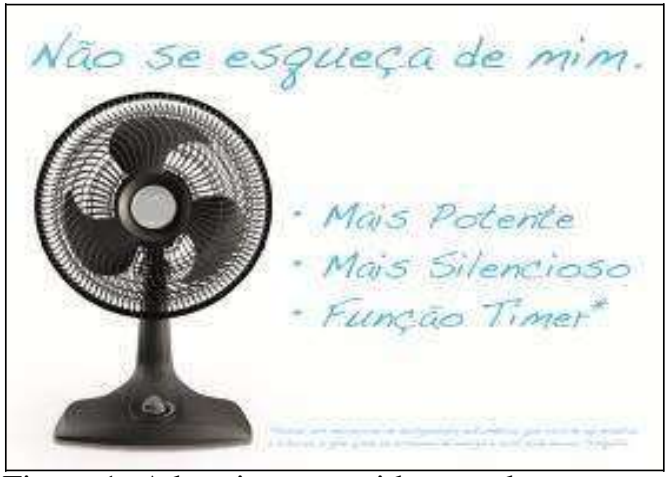

Figure 1- Advertisement without endorsement Source: Prepared by the authors (2012)

Note: Figures texts: "Don’t forget me. More Powerful; Quieter; Timer Function"

In the second block of the questionnaire, the respondents were asked to assess the product, by means of seven statements - [I would surely buy this new model; This new model is certainly better than the one I have now; In my opinion, this new model is the best choice; This new model will surely be a success; I will buy this new model, even though it costs a bit more than other similar models; I would certainly recommend this new model; I trust this new model] - which formed the dependent variable. All seven statements were assessed on a fivepoint Likert scale (from $1=$ totally disagree to $5=$ totally agree).

The third block requested demographic data on the respondents. We invited business administration students at a university and employees of a retail store in the state of São Paulo to participate in the survey, by sending them email messages. The great majority of students had already engaged in some gainful activity, meaning they had experience in making independent buying decisions with their own money. In turn, the retail store employees were chosen because their work with sale of durable goods theoretically should make them good evaluators of this product category. Each person invited to participate received a link to access the ads formulated for the experiment. According to Hair Junior et al. (2005), 30 observations are sufficient to carry out analysis of variance, but in this case our target was 50 observations per group, because we were worried that some respondents might not recognize the celebrities used in the study.

\section{DATA ANALYSIS}

To analyze the data we used descriptive statistics and analysis of variance (ANOVA), by means of the SPSS version 15.0.0 software. To test the hypotheses, we accepted a $10 \%$ significance level $(\mathrm{p}<0.10)$, a level considered acceptable in the applied social sciences (HAIR JUNIOR et al., 2005; FIELD, 2009). 


\section{RESULTS OF EXPERIMENT 1}

The final sample of this experiment was composed of 92 respondents, 34 men (37\%) and 58 women (63\%). Their average age was 30 years $(\square=9.20)$. The internal consistency of the seven items of the scale forming the dependent variable (evaluation) was considered satisfactory (Cronbach's alpha of 0.881 ) according to the recommendations of Hair Junior et al. (2005).

As expected, the evaluation of the product with celebrity endorsement was better than that without the endorsement $\left(\mathrm{M}_{\text {with endorsement }}=3.90\right.$ and $\mathrm{M}_{\text {without endorsement }}=3.33 ; \mathrm{t}(90)=3.050$; $\mathrm{p}<0.01)$. The results are presented in Figure 3.

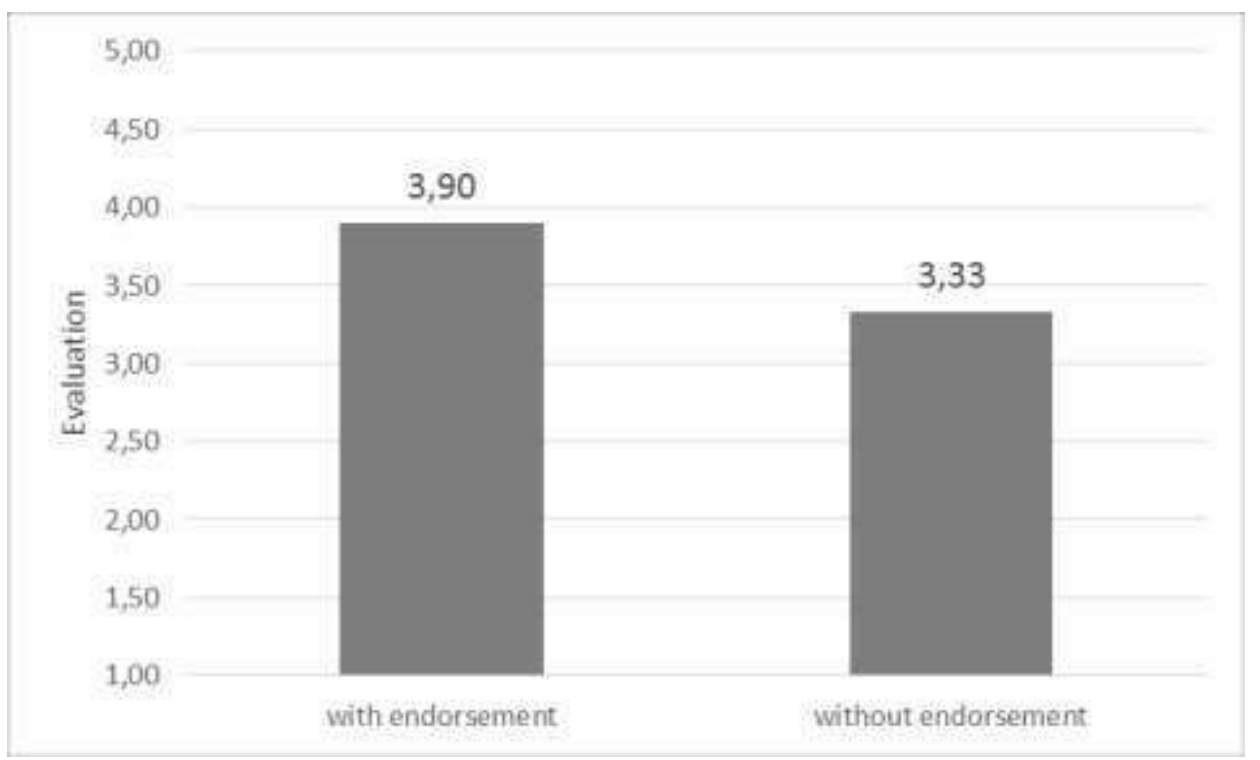

Figure 3 - Evaluation of the advertised product with and without celebrity endorsement

\section{DISCUSSION OF THE RESULTS OF EXPERIMENT 1}

The influence of celebrity endorsements in advertising has already been confirmed by other studies (AGRAWAL; KAMAURA, 1995; ROCKWELL; GILLES, 2009; CHOI et al., 2005). The results of this experiment show that the phenomenon is atemporal and recurrent in Brazil, justifying the use endorsement as a marketing strategy. Hence, our findings corroborate the results of previous studies that have demonstrated the influence of celebrity endorsements on individuals' judgment and buying behavior (McNAMARA, 2009; SLIBURYTE, 2009).

\subsection{THE EFFECT OF THE BRAND IN ADVERTISING WITH CELEBRITY ENDORSEMENT}

The objective of this study was to analyze the effect of the brand in advertising with endorsement by celebrities. The theory of diagnosticity proposes that in the process of assessing alternatives, individuals probably will distinguish diagnostic information from 
among all information available. Van Vallendael and Guignard (1992) identified that when the perceived diagnosticity of information is low, individuals' desire increases to find further information, for better evaluation.

Considering that the recognition of a brand reinforces the perception of benefits and reduces the risks perceived by consumers, we formulated the following hypotheses:

$\mathrm{H} 2 \mathrm{a}$ - The positive evaluation of a recognized brand will not depend on endorsement by celebrities.

$\mathrm{H} 2 \mathrm{~b}$ - An unrecognized brand will be evaluated more positively when endorsed by a celebrity.

$\mathrm{H} 2 \mathrm{c}$ - The evaluation of a recognized brand will be more positive than that of an unrecognized brand when the advertisement does not contain a celebrity endorsement.

\subsection{SELECTION OF THE STIMULI OF EXPERIMENTS 2 AND 3}

Only the advertisement used in Experiment 2 was changed in relation to Experiment 1. In this one, we used an ad with endorsement and another without endorsement by a celebrity for both brands, recognized and unrecognized. The recognized brand used was defined based on a list, presented to 10 college students, of the television brands most sold in the country. Then another group of college students $(n=32)$ evaluated the brands on the list generated by the first group, on a 10-point scale (from $1=$ poor brand to 10 - excellent brand). There was no significant difference between the best two brands (Sony and Samsung) at the 5\% level $(\mathrm{t}(30)=0.303 ; \mathrm{p}>0.10)$, so we used the brand (Sony) with the highest average $\left(\mathrm{M}_{\text {Sony }}=8.34\right.$; $\sigma=2.39)$.

For the unrecognized brand, we generated five hypothetical brand names by using a specific website for creation of names (http://nomesparaempresas.gratuita.com.br) and submitted them to a group of 47 university students for evaluation on a 10-point scale (from $1=$ this brand name is terrible for a new television model to $10=$ this brand name is excellent for a new television model). The brand "Lander" was chosen as the most suitable $(M=6.19 ; \sigma=$ 3.21).

To choose the celebrity, we first asked a group of eight college students to list names of celebrities they believed would be good to endorse a new television model. They generated a list of 26 names, which were presented to a second group of students $(n=32)$ for evaluation of the congruence of the celebrities to recommend a television model. Here we used a five-point Likert scale (from $1=$ this celebrity is not suitable to endorse a new television model to $5=$ 
this celebrity is very good to endorse a new television model). The TV host Luciano Huck was chosen as most congruent to endorse a new television model $(M=4.22 ; \sigma=1.13)$.

The questionnaire used in this experiment was the same as that used in Experiment 1, except for the first block presenting the advertisements, as shown in Figures 4, 5, 6 and 7.

\section{DATA ANALYSIS}

In Experiment 2 we used a complete $2 \times 2$ factorial design ( 2 brands [recognized versus unrecognized] x 2 endorsements [with versus without]). As before, we applied analysis of variance (ANOVA) to the data.

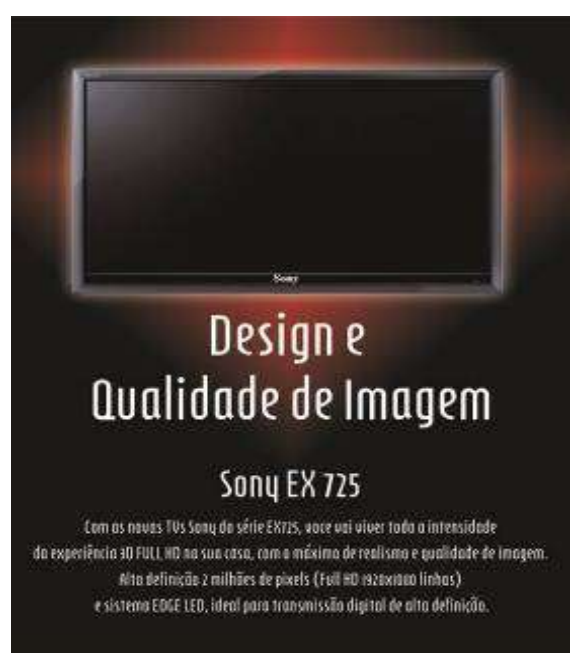

Figure 4 - Recognized brand without endorsement Source: Prepared by the authors (2012)

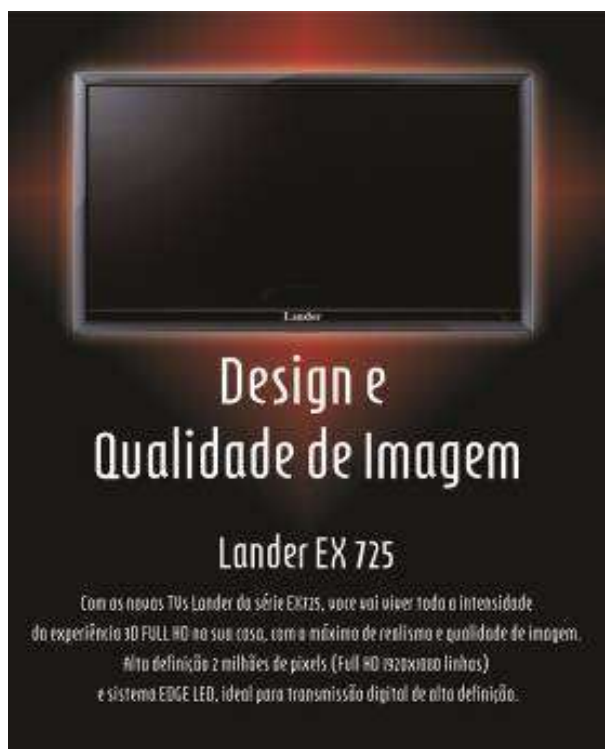

Figure 6 -Unrecognized brand without endorsement Source: Prepared by the authors (2012)

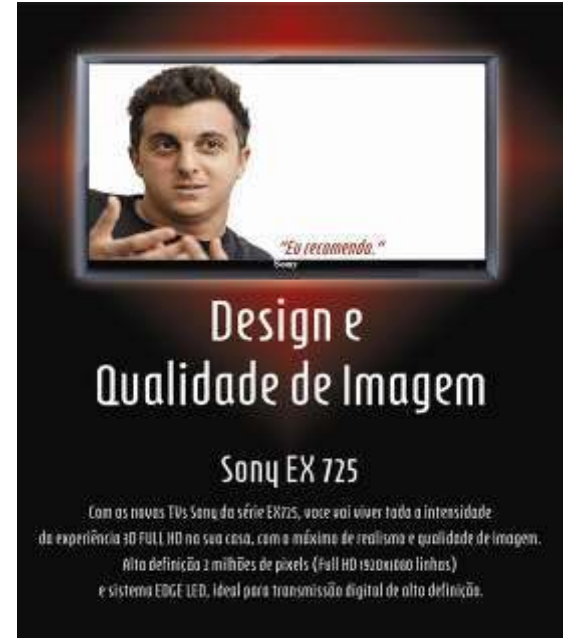

Figure 5 - Recognized brand with endorsement

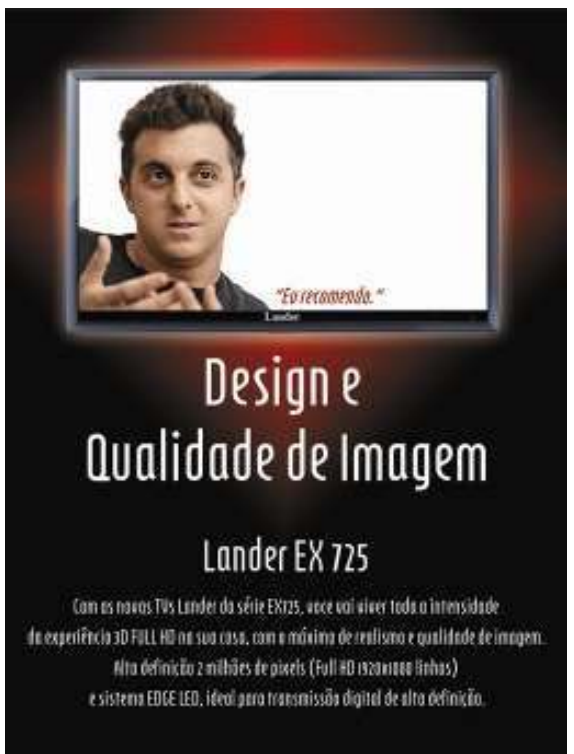

Figure 7 - Unrecognized brand with endorsement

\subsection{RESULTS OF EXPERIMENT 2}

The questionnaires were answered by 215 individuals, but four of them did not recognize the celebrity, because they could not indicate his name. We therefore excluded their 
responses, so that the final sample was composed of 211 respondents, 101 men (48\%) and 110 women $(52 \%)$, with average age of 31 years $(\sigma=10.82)$. There was relative balance between the groups because 102 people (48.3\%) evaluated the ad with the recognized brand and $109(51.7 \%)$ assessed the ad with the unrecognized brand. Likewise, 115 (55\%) evaluated the ad with endorsement while 96 (45\%) evaluated the ad without endorsement.

The manipulation of the brand recognition was successful, because there was a significant difference between the recognized brand ("I certainly recognize this television brand", with $1=$ totally disagree and $5=$ totally agree $)(\mathrm{M}=4.39)$ and invented brand $(\mathrm{M}=2.08, \mathrm{t}(207)=13.96 ; \mathrm{p}<0.01)$. We identified principal effect for brand $(\mathrm{F}(1.207)=16.622$; $\mathrm{p}<0.01)$ and principal effect for celebrity $(\mathrm{F}(1.207)=8.804 ; \mathrm{p}<0.05)$. We did not find any effect for the interaction between brand and celebrity $(\mathrm{F}(1.207)=1.19 ; \mathrm{p}>0.10)$.

The recognized brand was better evaluated in the quality attribute than the unrecognized brand $\left(\mathrm{M}_{\text {recognized }}=4.38\right.$ and $\left.\mathrm{M}_{\text {unrecognized }} 2.75, \mathrm{t}(204)=10.848 ; \mathrm{p}<0.01\right)$. The celebrity endorsement, however, did not significantly alter the quality assessment of the product with recognized brand $\left(\mathrm{M}_{\text {with endorsement }}=3.53\right.$ and $\left.\mathrm{M}_{\text {without endorsement }}=3.60, \mathrm{t}(100)=1.522 ; \mathrm{p}>0.10\right)$. In contrast, the unrecognized brand was positively influenced by the endorsement $\left(\mathrm{M}_{\text {with }}\right.$ endorsement $=3.04$ and $\left.\mathrm{M}_{\text {without endorsement }}=2.52, \mathrm{t}(102)=2.414 ; \mathrm{p}<0.05\right)$.

In the ANOVA we used the same aggregate evaluation items presented in item 2.1.2. The internal consistency of the evaluation variable's scale was considered satisfactory, with Cronbach's alpha of 0.847 , according to the recommendation of Hair et al. (2005).

As expected, the assessment of the product with the recognized brand was more positive than that of the unrecognized brand product $\left(\mathrm{M}_{\text {recognized }}=3.83\right.$ and $\mathrm{M}_{\text {unrecognized }}=$ $3.36=\mathrm{t}(209)=4.055 ; \mathrm{p}<0.05)$. With celebrity endorsement of both, the recognized brand continued being best evaluated $\left(\mathrm{M}_{\text {recognized }}=3.93\right.$ and $\mathrm{M}_{\text {unrecognized }}=3.59=\mathrm{t}(113)=2.107$; $\mathrm{p}<0.05)$. Without endorsement, however, the difference was even more significant $\left(\mathrm{M}_{\mathrm{recognized}}\right.$ $=3.71$ and $\left.\mathrm{M}_{\text {unrecognized }}=3.12=\mathrm{t}(94)=3.741 ; \mathrm{p}<0.01\right)$.

When comparing the evaluations of the recognized brand with and without endorsement, there was no significant difference $\left(M_{\text {recognized with endorsement }}=3.93\right.$ and $M_{\text {recognized }}$ without endorsement $=3.71=\mathrm{t}(100)=1.331 ; \mathrm{p}>0.10)$. However, the unrecognized brand with endorsement was better evaluated than the unrecognized brand without endorsement $\left(\mathrm{M}_{\text {unrecognized with endorsement }}=3.59\right.$ and $\left.\mathrm{M}_{\text {unrecognized without endorsement }}=3.12=\mathrm{t}(107)=2.869 ; \mathrm{p}<0.05\right)$. The data are summarized in Figure 8. 


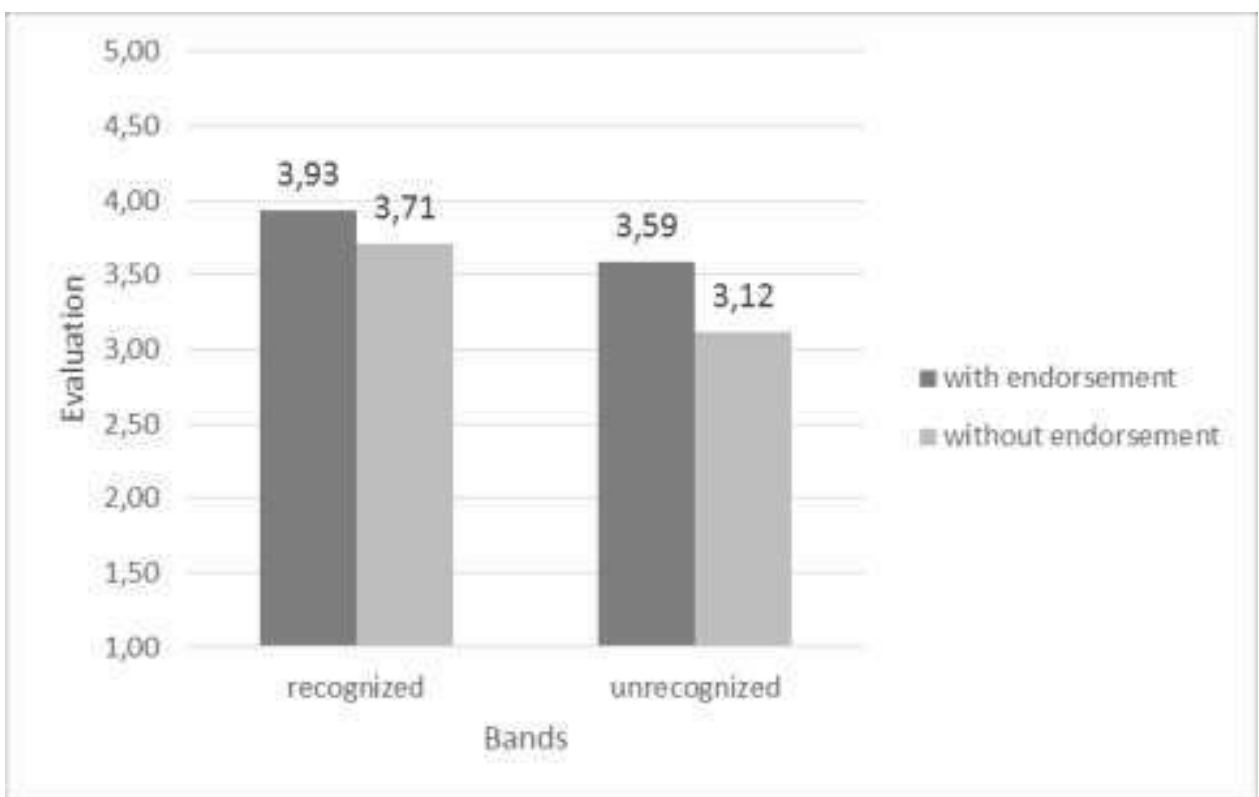

Figure 8 - Assessment of the recognized brand and unrecognized brand with and without celebrity endorsement

\subsection{DISCUSSION OF THE RESULTS OF EXPERIMENT 2}

The results obtained indicate the perceived superiority of the recognized brand in relation to the unrecognized brand, with or without the use of celebrity endorsement. It can be inferred that recognized brands do not greatly benefit from endorsement by celebrities. The unrecognized brand, however, was better evaluated when endorsed. This confirms hypothesis H2a, according to which the evaluation of a recognized brand does not depend on celebrity endorsement.

Also, while the unrecognized brand received a better assessment when endorsed, this evaluation was not as positive as the recognized brand, with or without endorsement. This confirmed hypothesis $\mathrm{H} 2 \mathrm{~b}$, according to which the evaluation of an unrecognized brand will be more positive when receiving celebrity endorsement.

Finally, the respondents rated the recognized brand as superior to the unrecognized brand, confirming hypothesis $\mathrm{H} 2 \mathrm{c}$, according to which a recognized brand will be better evaluated than an unrecognized brand without a celebrity endorsement.

\subsection{THE EFFECT OF BRAND WITH DIFFERENT LEVELS OF CONGRUENCE WITH THE CELEBRITY}

The use of celebrities in marketing communication is a relatively modern phenomenon, related to the development of mass communications media (ROCKWELL; GILES, 2009). The communication should be clear, objective and easily assimilated. In making the endorsement, the celebrity transfers his/her attributes or qualities to the product or brand. 
To increase the persuasive power of the endorsement on consumers, there should be congruence between the celebrity and object (GUREL; KAHLE, 2010). Congruence is the fit between the product or brand and the endorser's profile (KIM; NA, 2007). Famous athletes endorsing brands connected with their sport or a famous wine critic endorsing a determined wine brand are examples of good congruence between the celebrity and object. Because of this importance of congruence between the endorser and brand or product and its contribution to the assessment brand/product assessment, we formulated the following hypotheses:

$\mathrm{H} 3 \mathrm{a}$ - The evaluation of a recognized brand will not depend on the congruence of the celebrity with the product.

$\mathrm{H} 3 \mathrm{~b}$ - An unrecognized brand will be evaluated better when endorsed by a celebrity with high congruence, but the assessment will not be as favorable as that of a recognized brand. $\mathrm{H} 3 \mathrm{c}$ - An unrecognized brand endorsed by a celebrity with high congruence will be better evaluated than another unrecognized brand endorsed by a celebrity with low congruence.

\section{Experiment 3}

Television sets made by Sony (recognized brand) and Lander (unrecognized brand) were presented in ads with and without endorsement, also considering the congruence between the celebrity and product.

The selection of the endorser's stimulus for Experiment 2 indicated TV host Luciano Huck as the most congruent to endorse a new television model $(\mathrm{M}=4.22 ; \sigma=1.13)$ and also indicated that Cesar Cielo (Brazilian Olympic gold-medal swimmer) had the lowest congruence $(\mathrm{M}=2.53 ; \sigma=1.34=\mathrm{t}(31)=5.345 ; \mathrm{p}<0.01)$.

The data collection of Experiment 3 was similar to that in the previous experiments, the only difference being the groups of respondents.

\section{DATA ANALYSIS}

For Experiment 3 we used a complete 2 x 2 factorial design ( 2 brands [recognized versus unrecognized] $\mathrm{x} 2$ endorsements [with versus without]) and applied analysis of variance (ANOVA) to the data.

\subsection{RESULTS OF EXPERIMENT 3}

The questionnaires were answered by 212 individuals. Once again, four respondents did not recognize the celebrity so their responses were dropped, forming a final sample of 208 respondents. There was good balance of the groups, because 102 individuals (49\%) assessed ads promoting the recognized brand versus 106 (51\%) who evaluated ads for the 
unrecognized brand. Likewise, 89 (43\%) evaluated ads with endorsement by a celebrity with low congruence while the 119 (57\%) assessed ads with endorsement by a celebrity with high congruence.

The manipulation of the celebrity congruence stimulus was successful, as indicated by the significant difference between the celebrities with high and low congruence: Luciano Huck $\left(M_{\text {high congruence }}=3.70\right)$ and Cesar Cielo $\left(M_{\text {low congruence }}=3.09, t(106)=2.425 ; \mathrm{p}<0.01\right)$.

The manipulation of the brand recognition stimulus was also successful, indicating a significant difference between the recognized brand $\left(\mathrm{M}_{\text {recognized }}=4.31\right)$ and invented brand $\left(\mathrm{M}_{\text {unrecognized }}=1.95, \mathrm{t}(202)=14.648 ; \mathrm{p}<0.01\right)$. We did not find a principal effect for congruence $(\mathrm{F}(1.207)=2.290 ; \mathrm{p}>0.10)$, but we did verify a principal effect for brand $(\mathrm{F}(1.207)=34.515$; $\mathrm{p}<0.01)$. The effect of interaction between congruence and brand was significant at $10 \%$ $(\mathrm{F}(1.207)=2.908 ; \mathrm{p}<0.10)$.

The assessment of the quality of a product with unrecognized brand was better when the advertisement had an endorsement by the celebrity with high congruence with the product in comparison to endorsement by the celebrity with low congruence $\left(\mathrm{M}_{\text {high congruence }}=2.89\right.$ and $\left.\mathrm{M}_{\text {low congruence }}=2.45 ; \mathrm{t}(99)=2,24 ; \mathrm{p}<0.05\right)$.

With respect to the recognized brand, the use of endorsement did not influence the quality assessment $\left(\mathrm{M}_{\text {high congruence }}=4.08\right.$ and $\left.\mathrm{M}_{\text {low congruence }}=4.10, \mathrm{t}(98)=0.081 ; \mathrm{p}>0.10\right)$.

For the ANOVA we used the same aggregate evaluation items as identified in item 2.1.2. The internal consistency of the scale of the dependent variable was considered satisfactory according to the Cronbach's alpha value (0.847), as recommended by Hair Junior et al. (2005).

As expected, the evaluation of the product with recognized brand was more positive than that of the product with unrecognized brand $\left(\mathrm{M}_{\text {recognized }}=3.76\right.$ and $\mathrm{M}$ unrecognized $=$ $3.11=\mathrm{t}(206)=5.764 ; \mathrm{p}<0.01)$. The assessments of the recognized and unrecognized brands were significantly different when endorsed by the celebrities with high congruence with the

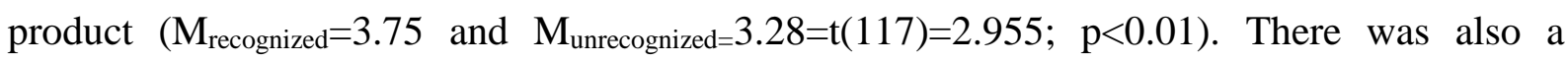
difference in the evaluations of the recognized and unrecognized brands when endorsed by the celebrity having low congruence with the product $\left(\mathrm{M}_{\text {recognized }}=3.77\right.$ and $\left.\mathrm{M}_{\text {unrecognized }}=2.92=\mathrm{t}(87)=5.691 ; \mathrm{p}<0.01\right)$.

The unrecognized brand with endorsement by the celebrity having high congruence was better evaluated than when endorsed by the celebrity with low congruence $\left(\mathrm{M}_{\text {high congruence }}=\right.$ 
3.28 and $\left.\mathrm{M}_{\text {low congruence }}=2.92=\mathrm{t}(104)=2.108 ; \mathrm{p}<0.05\right)$. In contrast, the endorsement by the celebrity having high congruence with the recognized brand did not influence its evaluation $\left(\mathrm{M}_{\text {high congruence }}=3.75\right.$ and $\left.\mathrm{M}_{\text {low congruence }}=3.77=\mathrm{t}(100)=151 ; \mathrm{p}>0.10\right)$. The results are presented in Figure 9.

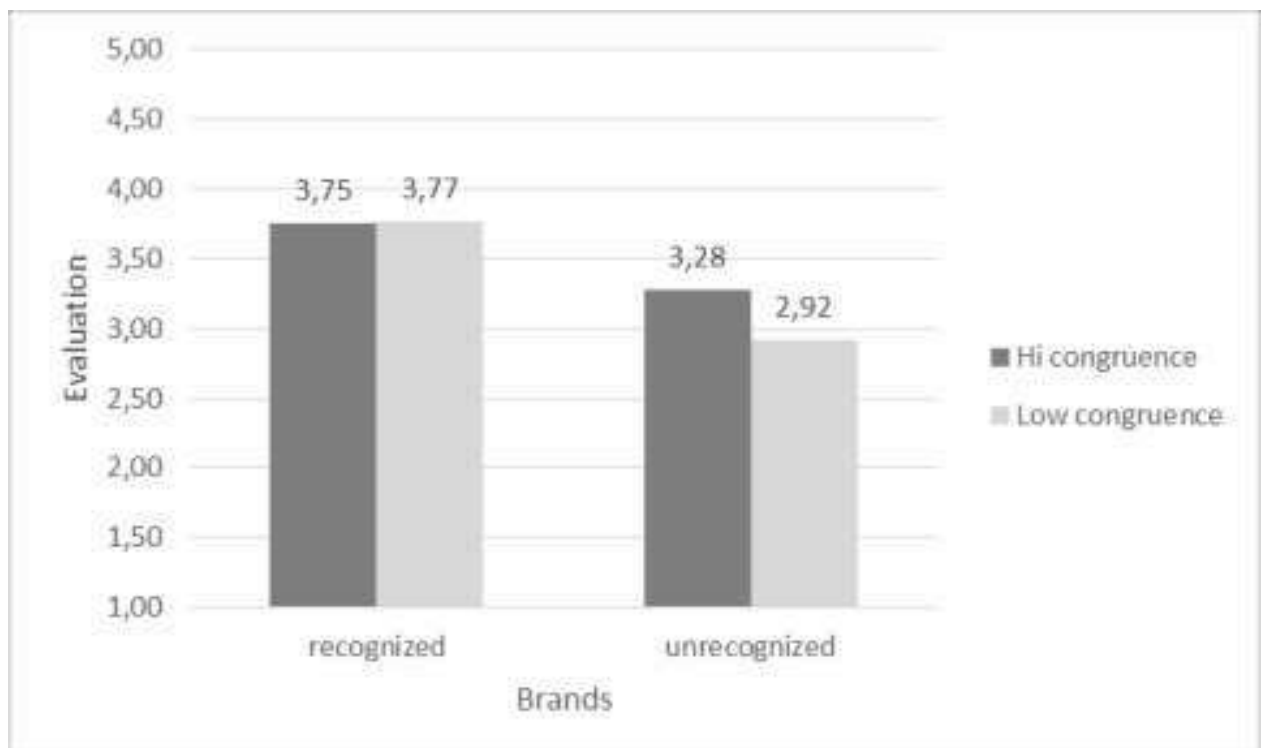

Figure 9 - Assessment of the recognized and unrecognized brands with endorsements by celebrities with high and low congruence

\subsection{DISCUSSION OF THE RESULTS OF EXPERIMENT 3}

The results of this experiment indicate the superiority of a recognized brand in relation to an unrecognized brand, even when the celebrity used in the advertising has high congruence with the product. For the unrecognized brand, the evaluation improved with endorsement with high congruence between celebrity and product.

Keller (2003) stressed the importance of brands to consumers. The objective of Experiment 3 was to analyze the effect of the brand in advertisements carrying endorsements by celebrities having high and low congruence with the product. We used varied stimuli to test (a) the recognized and unrecognized (invented) brand in ads endorsed by (b) celebrities with high and low congruence.

The results indicate that a recognized brand is typically perceived overall as superior to an unrecognized brand. Also, the quality attribute of the recognized brand was better assessed than the quality of the unrecognized brand. In all the analyses, the recognized brand was better evaluated, regardless of the type of endorsement. Furthermore, the use of endorsement by celebrities with high and low congruence did not improve the evaluation of the recognized brand. 
There was no influence on the evaluation of the unrecognized brand with endorsement with low congruence, but endorsement by the celebrity with high congruence improved its assessment. Although the general evaluation of the unrecognized brand was more positive when endorsed by the celebrity with high congruence, the quality attribute was not positively influenced.

For the recognized brand, the evaluation was always superior to that of the unrecognized brand, irrespective of the celebrity congruence, confirming hypothesis $\mathrm{H} 3 \mathrm{a}$, according to which the evaluation of a recognized brand does not depend on the congruence of the celebrity with the product.

The unrecognized brand was better evaluated when endorsed by the celebrity with high congruence with the product, but this was not sufficient to reach the assessment of the recognized brand with endorsement by the celebrity with high congruence. This confirmed hypothesis $\mathrm{H} 3 \mathrm{~b}$, that an unrecognized brand will be better evaluated when endorsed by a celebrity having high congruence with the product, but the assessment will not be as favorable as that of a recognized brand.

The unrecognized brand endorsed by the celebrity with high congruence was better evaluated than when endorsed by the celebrity with low congruence, thus confirming hypothesis $\mathrm{H} 3 \mathrm{c}$, according to which the evaluation of an unrecognized brand, when endorsed by a celebrity with high congruence with the product, will be better than when endorsed by a celebrity having low.

Based on the results presented, we can state that a recognized brand exerts more influence over consumers than celebrity endorsement. Furthermore, the effectiveness of celebrity endorsement can vary for different types of brands.

\section{GENERAL DISCUSSION AND LIMITATIONS}

In this section we discuss the results of the empirical survey in general and present its limitations, as well as suggest aspects worthy of future research on the theme.

\subsection{GENERAL DISCUSSION}

The results show that a recognized brand is the main reference for consumers, regardless of celebrity endorsement.

In Experiment 1, we sought to identify the phenomenon of celebrity endorsement, analyzing its influence in advertising. The intention was to verify whether endorsement is recurring and atemporal. The analyses evidence that endorsement by a celebrity in 
advertising, without identifying the brand, has a positive influence on consumers' assessment of the product.

In Experiment 2, we analyzed the effect of a recognized brand in advertisements endorsed and not endorsed by a celebrity. The results indicate that the evaluation of the product does not depend on celebrity endorsement, contrary to the result of Experiment 1, where the celebrity endorsement caused the product to be better evaluated when no brand was mentioned. This provides evidence that recognized brands have autonomy and exercise more influence on consumers than celebrity endorsement in advertising.

This finding corroborates the results of previous studies on the importance of brands for consumers, but makes an advance by demonstrating the power of the brand in moderating the effect of celebrity endorsement. The experiment also revealed that recognized brands are better evaluated than unrecognized brands, and that having a recognized brand is the main attribute in evaluation of the product by consumers, in line with the findings of Rao and Monroe (1989) and Aaker (1997).

For Experiment 3, we added the concept of congruence between the celebrity and product, The results ratified that a recognized brand does not depend on celebrity endorsement and is better evaluated than an unrecognized brand. We did not observe an influence on the quality evaluation of the recognized brand even with endorsement of a celebrity having high congruence with the product. The results of this experiment support the observations of Kim and $\mathrm{Na}$ (2007) about the importance of congruence in celebrity endorsement, and also indicate that endorsement by a celebrity does not affect the perceived intrinsic quality of a product with a recognized brand, in line with Keller, Heckler and Houston (1998), who found that a recognized brand name is the main reference for consumers. This suggests that celebrity endorsement is less relevant than the presence of a recognized brand in advertising.

\section{ACADEMIC IMPLICATIONS}

The overall aim of this study was to shed more light on the phenomenon of "celebrity endorsement" in advertising, and in this line, to advance knowledge both of the phenomenon of endorsement and the effect of brand on it. Previous studies have been published on the influence of celebrity endorsement of products (TILL; SHIMP, 1998; CHARBONNEAU; GARLAND, 2005), but few have addressed the theme of endorsement for different types of brands. 
One of the main contributions of this study regards the development of the experiments performed, which can serve as a methodological model for other researchers to benefit from this technique, already well established in other areas of knowledge, and apply it specifically in the field of marketing.

Another contribution is to enhance understanding of the strategy of celebrity endorsement and how its effectiveness can vary according to the type of brand and the congruence between the celebrity and product. By evidencing the autonomous power of the recognized brand, this study corroborates previous studies about brands and their influence on consumers, including the assessment of products, specifically showing that recognized brands are better evaluated by consumers and can even become synonyms for quality in their eyes (AAKER, 1997).

The contributions to the understanding of congruence between celebrity and product are relevant. International academic studies have focused on the development of theoretical models to evaluate the potential of celebrities to endorse products in advertising. The analysis of our empirical data indicates that congruence between celebrity and product is fundamental for better evaluation of the endorsed product (GUREL; KAHLE, 2010; KIM; NA, 2007). This study also contributes to the understanding of different types of endorsement (with high and low congruence) and its influence on the assessment of different types of brands.

A further contribution is that high congruence influences the evaluation of consumers, promoting a more positive evaluation of the product. This demonstrates that positive aspects of celebrities with high congruence are transferred to the products, corroborating previous studies on the theme. In this respect, our findings add knowledge about celebrity endorsement and the level of congruence, as moderated by different types of brands.

Researchers in other countries have sought to understand the influence of celebrity on individuals, but few studies have been carried out on this theme in Brazil. In this study we applied the state of the art aiming to confirm the theoretical hypotheses developed in international studies in the Brazilian context. The empirical results contain elements that Brazilian academics can use to expand knowledge about the use of celebrities in marketing and to obtain relevant theoretical references.

\subsection{MARKETING IMPLICATIONS}

Marketing and communication professionals constantly face the challenge of deciding whether or not to use celebrity endorsement in advertising of products. In this respect, this 
study contributes with a broad range of information and techniques that can be used to understand the different types of endorsement strategies and apply them in defining promotional campaigns for launch of new brands or repositioning of existing ones.

Another contribution is the identification that celebrities with high congruence positively influence the evaluation of products. We recommend that marketing managers develop the quality attribute of the brand with celebrities who have high congruence or who at least have some type of experience with the product, to increase their power of persuasion over consumers.

The respondents in the experiments were more sensitive to endorsement by a celebrity with high congruence than by a celebrity having low congruence. In particular, endorsement by the celebrity having high congruence made a significant contribution to the evaluation of the invented brand.

Marketing and communication professionals can use the results of this study, with different types of endorsement, to formulate strategy on the use of celebrity endorsement in advertising.

\subsection{LIMITATIONS AND POSSIBLE EXTENSIONS}

Despite all the precautions taken during the execution of any study, the possibility of biases will always be present. But limitations of this nature also present an opportunity for advancement and point to avenues for future research.

The use of undergraduate business administration students as respondents might have influenced the results, since they already had knowledge of the marketing area. Also, the inclusion of employees of a retail chain store might have influenced the results, since they answered the questionnaire in the workplace, which might have influenced their opinions. We suggest that future studies use random samples of consumers to assure generalization of the results.

We also recommend that future studies vary the types of products, the celebrity profiles and types of brands. The stimuli described here are also a limitation, since we used undergraduate college students through brainstorming to help choose the stimuli.

In conclusion, due to the relative dearth of studies investigating the use of celebrity endorsement in Brazil, there are many opportunities for future research, with different categories of products or services, as well as different types of brands. 
* We thank the reviewers and editors for their suggestions during the evaluation process.

\section{REFERENCES}

AAKER, J. Dimensions of brand personality. Journal of Marketing Research, v. 34, n. 2, p. 347-356, 1997.

AILAWADI, K. L.; LEHMANN, D. R.; NESLIN, S. A. Revenue premium as an outcome measure of brand equity'. Journal of Marketing, v. 67, p. 1-17, 2003.

AGRAWAL, J.; KAMAKURA, W. A. The economic worth of celebrity endorsers: An event study analysis. Academic Research Library, v. 59, n. 3, p. 56-62, 1995.

ALEX, J. Consumer evaluations of product line brand extension. The IUP Journal of Brand Management, v. 8, n. 1, p. 22-35, 2011.

BANYTÈ, J.; STONKIENÈ, E.; PILIGRIMIENÈ, Z. Selecting celebrities in advertising: the case of Lithuanian sports celebrity in non sport product advertisement. Economic and management, v. 16, p. 1215-1224, 2011.

BATRA, R.; AHUVIA, A.; BAGOZZI, R. Brand love. Journal of Marketing, v. 76, n. 2, p. $1-16,2012$.

BAKER, M.; GILBERT, A. The impact of physically attractive models on advertising evaluations. Journal of Marketing Research, v. 14, n. 4, p. 538-555, 2007.

CAPUTO, E. S.; MACEDO, M. A. S.; NOGUEIRA, H. G. P. Avaliação de marcas: uma aplicação ao caso Bombril. RAE - Eletrônica, v. 7, n. 2, p. 1-15, 2008.

CHARBONNEAU, J.; GARLAND, R. Talent: looks or brains? New Zealand advertising practitioners' views on celebrity and athlete endorsers. Marketing Bulletin, v. 16, n. 3, p. 110, 2005.

CHOI, S. M.; RIFON, N. J. Who is the celebrity in advertising? Understanding dimensions of celebrity images. The Journal of Popular Culture, v. 40, n. 2, p. 304-324, 2007.

CHOI, S. M.; LEE, W.; KIM, H. Lessons from the rich and famous: a cross-cultural comparison of celebrity endorsement in advertising. Journal of Advertising, v. 34, n. 2, p. 85-98, 2005.

FRIEDMAN, H.; FRIEDMAN, L. Endorser effectiveness by product type. Journal of Advertising Research, v. 19, n. 5, p. 63-71, 1979.

GONÇALVES FILHO, C.; SOUKI, G. Q.; GONÇALVES, C.A. Valor das marcas (brand equity) para consumidor: desenvolvimento e validação de um instrumento de mensuração no setor automotivo. Revista Eletrônica de Ciências Administrativa (RECADM), v. 8, n. 1, p. 106-118, 2009.

GUREL, E.; KAHLE, L. Celebrity endorsements and advertising effectiveness: The importance of value congruence. Advances in Consumer Research, v. 37, n. 3, p. 807-808, 2010. 
HAIR JUNIOR, J. F. et al. Análise multivariada de dados. 6. ed. Porto Alegre: Bookman, 2005.

KAHLE, L.; HOMER, P.M. Physical attractiveness of the celebrity endorser: a social adaptation perspective. Journal of Consumer Research, v. 11, n. 4, p. 954-961, 1985.

KELLER, K. L.; HECKLER, S.; HAUSTON, M. J. The effects of brand name suggestiveness on advertising recall. Journal of marketing, v. 62, n. 1, p. 48-57, 1998.

Building, measuring, and managing brand equity. 2. ed. Upper Saddle River, NJ:

Prentice Hall, 2003.

KIM, Y.; NA, J. Effects of celebrity athlete endorsement on attitude towards the product: the role of credibility, attractiveness and the concept of congruence. International Journal of Sports Marketing \& Sponsorship, v. 8, n. 4, p. 310-320, 2007.

McNAMARA, K. Publicising private lives: celebrities, image control and the reconfiguration of public space. Social and Cultural Geography, v. 10, n. 1, p. 1-23, 2009.

MCCRACKER, G. Culture and consumption: a theoretical account of the structure and movement of the cultural meaning of consumer goods. Journal of Consumer Research, p. 13, n. 1, p. 71-85, 1986.

MCCRACKER, G. Who is the celebrity endorser? Cultural foundations of the endorsement process. Journal of Consumer Research, p. 16, n. 3, p. 310-321, 1989.

MEYERS, E. Can you handle my truth?: authenticity and the celebrity star image. Journal of Popular Culture, v. 42, n. 5, p. 890, 2009.

MISRA, S.; BEATTY, S. Celebrity spokesperson and brand congruence: an assessment of recall and affect. Journal of Business Research, v. 21, n. 2, p. 159-173, 1990.

PETTY, R. D.; D’ROZARIO. The use of dead celebrities in advertising and marketing. Journal of Advertising, v. 34, n. 4, p. 37-48, 2009.

RAO, A.; MONROE, K. T. The effect of price, brand name, and store name on buyers' perceptions of product quality: an integrative review. Journal of Marketing Research, v. 26, n. 3, p. 351-357, 1989.

ROCKWELL, D.; GILES, DAVID, C. Being a celebrity: a phenomenology of fame. Journal of Phenomenological Psychology, v. 40, n. 2, p. 178-210, 2010.

RUST, R.; LEMON, K.; ZAITHALML, V. Return on marketing: using customer equity to focus marketing strategy. Journal of Marketing, v. 68, n. 1, p. 109-127, 2004.

SHIMP, T. Advertising promotion: supplemental aspects of integrated marketing communications. 5. ed. Fort Worth, TX: Dryden Press, 2000.

SCHMIDT, A. M. R.; GUIMARÃES, H. B. Condições e impacto das políticas de marca em empresas nacionais de bens de consumo. Revista de Administração, v. 20, n. 1, p. 60-64, 1985. 
SLIBURYTE, L. How celebrities can be used in advertising to the best advantage? World Academy of Science, Engineering and Technology, v. 58, n. 2, p. 934-939, 2009.

TILL, B.; SHIMP, T. Endorsers in advertising: the case of negative celebrity information. Joumal of Advertising, v. 27, n. 1, p. 67-82, 1989.

TRIPP, C.; JENSEN, C.; CARLSON, L. The effects of multiple product endorsements by celebrities on consumers' attitudes and intentions. Journal of Consumer Research, v. 20, n. 4, p. 535-547, 1994.

VAN WALLENDAEL, L. R.; GUIGNARD, Y. Diagnosticity, confidence, and the need for information. Journal of Behavioral Decision Making, v. 5, n. 1, p. 25-37, 1992. 